\title{
Alcohol Consumption Among Inflammatory Rheumatic Patients: A Survey From Turkey
}

\author{
İnflamatuvar Romatizmal Hastaların Alkol Tüketim Özellikleri: Türkiye’den Bir Araştırma
}

\begin{abstract}
H. Fatih ÇAY, ${ }^{1}$ Özge İLLEEZ, ${ }^{2}$ Hilal KOCABAŞ, ${ }^{3}$ İlhan SEZER, ${ }^{1}$ Ece KAPTANOĞLU, ${ }^{4}$ Cahit KAÇAR ${ }^{5}$
${ }^{1}$ Department of Physical Medicine and Rehabilitation, Antalya Training and Research Hospital, Division of Rheumatology, Antalya, Turkey;

${ }^{2}$ Department of Physical Medicine and Rehabilitation, Gümüşhane State Hospital, Gümüşhane, Turkey;

${ }^{3}$ Department of Physical Medicine and Rehabilitation, Konya Training and Research Hospital, Division of Rheumatology, Konya, Turkey; ${ }^{4}$ Department of Physical Medicine and Rehabilitation, Medical Faculty of Cumhuriyet University, Division of Rheumatology, Sivas, Turkey;

${ }^{5}$ Department of Physical Medicine and Rehabilitation, Medical Faculty of Akdeniz University, Division of Rheumatology, Antalya, Turkey
\end{abstract}

Objectives: In this study, we aimed to evaluate alcohol consumption of Turkish rheumatic patients.

Patients and methods: A total of 332 subjects [185 males and 147 females; mean ages of $41.2(95 \% \mathrm{Cl} 39.5-$ 43.0) and $45.2(95 \% \mathrm{Cl} 43.4-47.1)$ years, respectively] with rheumatoid arthritis (RA), ankylosing spondylitis (AS) and healthy controls were questioned regarding their alcohol habits. Alcohol consumers were asked to fill out the Turkish version of the Michigan Alcoholism Screening Test (MAST).

Results: A total of $37.3 \%$ of all subjects were alcohol consumers. Nearly $50 \%$ of males and $20 \%$ of females drank alcohol. Rheumatoid arthritis group had the lowest rate of alcohol consumption $(23.0 \%)$, while healthy controls had the highest rate $(45.6 \%)$. The mean MAST scores were 3.02 (95\% Cl: 2.36-3.69) and $3.13(95 \%$ $\mathrm{Cl}$ : 1.76-4.5) for the AS and RA groups, respectively, indicating statistically lower rate compared to the healthy controls [4.94 (95\% Cl: $4.14-5.73)(p<0.001)]$. An analysis of the MAST scores by categories revealed that most of the alcohol abusers / alcoholics were in the healthy control group.

Conclusion: Our results showed that alcohol consumption, an important public health problem, has not been regarded as a major issue for the patients with rheumatic diseases. Further studies are required to evaluate the potential factors which may play a role in the alcohol consumption habits of rheumatic patients.

Key words: Alcohol dependency; ankylosing spondylitis; Michigan Alcoholism Screening Test; rheumatoid arthritis.
Amaç: Bu araştırmada ülkemizdeki romatizmal hastaların alkol kullanım alışkanlıkları değerlendirildi.

Hastalar ve yöntemler: Romatoid artrit (RA), ankilozan spondilit (AS) hastalarından ve sağlıklı kontrollerden oluşan toplam 332 denek [185 erkek, 147 kadın; yaş ortalamaları sırası ile 41.2 (\%95 GA 39.5-43.0) ve 45.2 (\%95 GA 43.4-47.1) yıl], alkol kullanım alışkanlığı olup olmadığına yönelik olarak sorgulandı. Alkol kullanım alışkanlığı olanlardan Michigan Alkolizm Tarama Testi'nin (MATT) Türkçe versiyonunu yanıtlamaları istendi.

Bulgular: Deneklerin toplam \%37.3'ü alkol kullanıyordu. Erkeklerin yaklaşık \%50'si, kadınların ise \%20'si alkol tüketim alışkanlığına sahipti. En düşük alkol kullanım oranı RA grubunda (\%23.0), en yüksek oran ise sağlıklı kontrol grubunda (\%45.6) idi. Ortalama MATT skoru, RA ve AS grupları için sırasıyla 3.02 (\%95 GA: 2.36-3.69) ve 3.13 (\%95 GA: 1.76-4.5) olarak bulundu ve her iki değer de kontrol grubuna ait değerden istatistiksel olarak anlamlı oranda küçüktü [4.94 (95\% GA: 4.14-5.73) p<0.001]. Michigan Alkolizm Tarama Test skorunun kategorize edilmesi ile yapılan analiz sonucunda alkol bağımlıı̆ı olan deneklerin büyük oranda sağlıklı kontrol grubunda olduğu görüldü.

Sonuç: Bizim sonuçlarımıza göre, önemli bir halk sağlığı sorunu olan alkol tüketiminin romatizmal hastalar arasında önemli bir sorun yaratacak boyutta olmadığı ortaya çıkmışıır. Romatizmal hastaların alkol tüketim alışkanlıkları üzerinde rol oynayan potansiyel faktörlerin daha geniş kapsamlı çalışmalarla araştıııması gerekmektedir.

Anahtar sözcükler: Alkol bağımlılığı; ankilozan spondilit; Michigan Alkolizm Tarama Testi; romatoid artrit. 
Alcohol consumption is considered to be a one of the coping mechanisms for stressful conditions such as chronic pain ${ }^{[1]}$ and chronic arthritis patients have been accused of consuming alcohol for its analgesic effect. ${ }^{[2]}$ Myllykangas-Luosujärvi et al. ${ }^{[3,4]}$ reported two opposite trends in incidences of alcohol-related deaths associated with rheumatoid arthritis (RA) and ankylosing spondylitis (AS) patients in Finland. Susceptibiliy to alcohol abuse varies greatly among individuals from different ethnic, religious, and cultural backgrounds. The alcohol per capita consumption rate was found to be between 0 and 8.47 liters per year in different countries of Asia, with the lowest and highest rates belonging to Iran and Thailand, respectively. ${ }^{[5]}$ According to information gathered from an article in the Turkish national newspaper concerning trends in alcohol consumption, the rate of "alcohol-nonconsumers" among Turkish people over 15 years of age was reported to range from $61-83 \%{ }^{[6]}$ Scant medical literature exists which has analyzed the alcohol consumption habits of patients with rheumatic diseases; therefore, in this study, we aimed to explore the alcohol consumption habits of Turkish rheumatic patients to determine whether they have a problem with alcohol abuse.

\section{PATIENTS AND METHODS}

This investigation was performed in rheumatology outpatient clinics of the Physical Medicine and Rehabilitation Departments of three different centers in Turkey: Akdeniz University Medical Faculty Hospital, Antalya, Antalya Education and Research Hospital, and Cumhuriyet University Medical Faculty Hospital, Sivas. The basic inclusion criteria were being 18-years-old or older and being able to read and write. A total of 332 subjects (185 males, 147 females) were included in this study. The healthy control group was composed of 136 subjects while the AS group had 122 and the RA group had 74 . The two different disease groups were composed of patients with RA and AS. The selection of patients was performed according to the 1987 American College of Rheumatology (ACR) criteria for RA and The European Spondyloarthropathy Study Group (ESSG) criteria for spondyloarthropathy. ${ }^{[7,8]}$ The control group was selected from healthy volunteers by considering the mean ages of the previous two groups as a whole. Subjects with known metabolic and endocrine diseases, including diabetes mellitus (DM) and thyroid dysfunctions, or hepatic diseases were excluded from the study. The demographic characteristics of all of the subjects, including the maximum duration of official education, were recorded, and all were asked a "screening question" about whether they drank alcohol or not to discriminate between those who consumed alcohol and those who did not. The answer was considered a "yes" even if there had only been one episode of alcohol consumption in their lives. The subjects who answered "yes" for the first question were designated as "alcohol-consumers" while the ones who answered "no" were designated as "alcohol non-consumers". Subsequently, the "alcoholconsumers" were asked to fill out the Turkish version of the Michigan Alcoholism Screening Test (MAST), which had previously been proven valid. ${ }^{[9]}$ Beside the comparison of means, the MAST score was transformed into a categoric variable. The consumers with a MAST score of 0-4 were considered to be "problem-free drinkers" while those with a MAST score of 5-9 were considered to be "probable alcohol abusers", and those with a MAST score of 10 points or more were classified as "probable alcoholics". ${ }^{[10]}$ An alternative categorization of the MAST score was applied if the cut-off point was 5 (i.e. any MAST score which is equal or greater than 5 stands for alcohol dependence) or 9 (i.e. any MAST score which is equal or greater than 9 stands for alcohol dependence). ${ }^{[9]}$

Additionally, the frequency of alcohol consumption and the types of primary and secondary choices of alcoholic beverage were recorded based on the information provided by the subjects. The alcohol consumption rates were indirectly investigated by the question: "Do you have any first-degree relative(s) who has an alcohol consumption habit?". The answer was accepted as "yes" even if only one person had this habit. The study protocol was approved by the local ethics committee of the Akdeniz University Medical Faculty.

\section{Statistical analysis}

One-way analysis of variance (ANOVA) with Tukey's correction was applied to compare the mean ages of the subjects in the disease and control groups. Independent sample t-test was used to compare the means of other continous variables. The chi-square and Fisher's exact tests were used to explore the differences in categoric variables among the groups. Bonferroni's correction was applied to the chi-square test to evaluate the source of difference between "alcohol-consumers of different genders" among disease groups. All statistical analyses were performed by using the SPSS version 13.0 software package (SPSS Inc., Chicago, Illinois, USA), and a statistical significance value of $\mathrm{p}<0.05$ was accepted. 


\begin{tabular}{|c|c|c|}
\hline & Mean \pm SD & $95 \% \mathrm{CI}$ of the mean \\
\hline \multicolumn{3}{|l|}{ Gender } \\
\hline Males $(n=185)$ & $41.2 \pm 12.0$ & $39.5-43.0$ \\
\hline Females $(\mathrm{n}=147)$ & $45.2 \pm 11.3$ & $43.4-47.1$ \\
\hline \multicolumn{3}{|l|}{ Disease groups } \\
\hline Rheumatoid arthritis $(\mathrm{n}=74)$ & $50.8 \pm 11.3^{\star} \dagger$ & $48.2-53.4$ \\
\hline Controls $(n=136)$ & $42.8 \pm 10.5$ & $41.0-44.6$ \\
\hline Ankylosing spondylitis $(\mathrm{n}=122)$ & $38.5 \pm 11.3^{\star *}$ & $36.4-40.5$ \\
\hline
\end{tabular}

\section{RESULTS}

The mean ages of the subjects are seen in Table 1. Among the 332 subjects, 124 (37.3\%) were designated as "alcoholconsumers" based on their personal declaration. Among this group, the males were significantly more predominant than females $(75.8 \%$ versus $24.2 \%$, respectively; $\mathrm{p}<0.001)$. The mean age of the "alcoholconsumers" was slightly lower than for the "nonconsumers" ( $41.3 \pm 11.5$ versus $44.0 \pm 11.9$, respectively; $\mathrm{p}=0.0045)$. The rate of "alcohol-consumers" without taking into consideration the disease groups was 50.8\% for males and $20.4 \%$ for females $(\mathrm{p}<0.001)$. The rates of alcohol consumption for the AS and RA patients without considering gender differences were $36.9 \%$ and $23.0 \%$, respectively. The alcohol consumption rate of the control group was $45.6 \%$, and the rate of "alcohol consumers" in the RA group was statistically lower than that of both the control and AS groups $(\mathrm{p}=0.0012$ and $\mathrm{p}=0.042$, respectively). There were significant differences between genders when the AS group was compared with the control and RA groups (Table 2). A habit of alcohol consumption in at least one person other than the study subject was present in 104 (31.9\%) of the first-degree relatives of the total subjects, with a rate of $39.8 \%$ among the "alcohol-consumers" and $27.1 \%$ among the "non-consumers". More than half (51.4\%) of the females had at least one first-degree relative with an alcohol consumption habit. This rate was as low as $16.1 \%$ among male subjects $(\mathrm{p}<0.001)$.

About $41.1 \%$ of all the "alcohol consumers" declared no specific type of alcoholic beverage as their primary choice. The most preferred type of alcoholic beverage was beer with $33.9 \%$. Raki, wine, and other types of beverages were preferred with rates of $13.7 \%, 6.5 \%$, and $4.8 \%$, respectively. Most of the "alcohol consumers" (92.\%) in our study also declared no specific type of alcoholic beverage as the secondary choice. Most of the "alcohol-consumers" (29.8\%) consumed alcohol at a frequency of two-four times per year. About 17.7\% of all of the consumers drank alcohol only once a year. About $50.8 \%$ of all the consumers in our study consumed one-three glasses of wine, beer, or the equivalent amount of alcohol. Among the 124 "alcohol consumers", $78.2 \%$ declared no specific reason for their alcohol consumption. Eighteen of the 124 subjects (14.5\%) consumed alcohol for pleasure while only nine $(7.2 \%)$ declared that they consumed alcohol for pain relief or as a sleep aid.

\begin{tabular}{|c|c|c|c|c|c|}
\hline & \multicolumn{2}{|c|}{ Male consumers } & \multicolumn{2}{|c|}{ Female consumers } & \multirow[b]{2}{*}{$p$} \\
\hline & $\mathrm{n}$ & $\%$ & $\mathrm{n}$ & $\%$ & \\
\hline $\begin{array}{l}\text { Controls } \\
\text { versus }\end{array}$ & 42 & 66.1 & 21 & 33.9 & $0.577^{\star}$ \\
\hline Rheumatoid arthritis & 10 & 58.8 & 7 & 41.2 & \\
\hline $\begin{array}{l}\text { Controls } \\
\text { versus }\end{array}$ & 42 & 66.1 & 21 & 33.9 & $0.00014^{*}$ \\
\hline Ankylosing spondylitis & 43 & 95.6 & 2 & 4.4 & \\
\hline $\begin{array}{l}\text { Ankylosing spondylitis } \\
\text { versus }\end{array}$ & 43 & 95.6 & 2 & 4.4 & $0.001^{\star}$ \\
\hline Rheumatoid arthritis & 10 & 58.8 & 7 & 41.2 & \\
\hline
\end{tabular}




\begin{tabular}{|c|c|c|c|c|c|c|}
\hline & \multicolumn{2}{|c|}{ Problem-free drinkers } & \multicolumn{2}{|c|}{ Probable alcohol abusers } & \multicolumn{2}{|c|}{ Probable alcoholics } \\
\hline & $\mathrm{n}$ & $\%$ & $\mathrm{n}$ & $\%$ & $\mathrm{n}$ & $\%$ \\
\hline \multicolumn{7}{|l|}{ Gender } \\
\hline Males & 51 & 55.4 & 37 & $40.2^{*}$ & 4 & 4.3 \\
\hline Females & 24 & 82.8 & 5 & $17.2^{*}$ & 0 & 0 \\
\hline \multicolumn{7}{|l|}{ Disease groups } \\
\hline Controls & 32 & 51.6 & 31 & 70.5 & 12 & 80.0 \\
\hline Ankylosing spondylitis & 26 & 41.9 & 13 & 29.5 & 3 & 20.0 \\
\hline Rheumatoid arthritis & 4 & 6.5 & 0 & 0 & 0 & 0 \\
\hline
\end{tabular}

The personel beliefs of the subjects regarding the relationship between alcohol consumption and rheumatic disease was also investigated. Most of the alcohol consumers declared that they do not believe such a relationship exists or they had no idea that there was any relationship. Only $4 \%$ declared that they believed in the presence of such a relationship.

The mean MAST scores of "alcohol-consumers" was not statistically different among males and females [4.29 (95\% CI: 3.67-4.92) versus 3.14 (95\% CI: 2.283.99), respectively], and the mean MAST score of the control group was 4.94 (95\% CI: 4.14-5.73). These same scores were 3.02 (95\% CI: 2.36-3.69) and 3.13 (95\% CI: 1.76-4.5) for the AS and RA groups, respectively. The differences in the MAST scores between these groups were statistically significant at $\mathrm{p}<0.001$. After categorizing the MAST scores into three subgroups, $55.4 \%$ of the male and $82.8 \%$ of the female "alcoholconsumers" were in the "problem-free drinker" group. The rate of "probable alcohol abusers" was 40.2\% for males and $17.2 \%$ for females $(p=0.026)$. All of the "probable alcoholics" $(\mathrm{n}=4)$ were males (Table 3). According to the MAST cut-off score of 5, 60.5\% of "alcohol-consumers" were determined to be "problemfree", and $37.1 \%$ were "probable alcoholics". If the MAST cut-off value was 9 , only $6.5 \%$ of all consumers were defined as "probable alcoholics".

The relationship between the alcohol consumption habits and educational status of the subjects was analyzed, with the educational status being subdivided into three categories according to the maximum duration of official education. The first category was "primary school graduates", comprised of those who had a maximum of five years of education. This was followed by the "intermediary school graduates" with a maximum of eight years of eduacation and "high school graduates" with 10 or more years of official education.
Using the cut-off value of 5 for the MAST score, the rates of "probable alcoholics" were $61.8 \%$ for "primary school graduates", $37.5 \%$ for "intermediary school graduates", and $26.9 \%$ for "high school graduates" $(\mathrm{p}=0.020)$. A similar analysis using a cut-off value of 9 for the MAST score revealed no statistically significant relationship.

\section{DISCUSSION}

To the best of our knowledge, there has been no report concerning the alcohol consumption properties of living rheumatic patients. Myllykangas-Luosujärvi et al. ${ }^{[3,4]}$ previously reported the results of two different investigations performed using a retrospective analysis of the medical records of deceased patients via the National Insurance Act of Finland. According to these reports, the relative risk of mortality due to alcoholrelated events was higher for AS patients and lower for RA patients than for the general population for both genders. However, no connection was assumed in these studies with regard to the rate of alcohol consumption in living patients since that was not the intent of the research.

It is a known fact that men in our country consume more alcohol than women. The Ministry of Health has reported that the rate of women aged 15 years and older who do not consume alcohol was $93 \%$. This rate was $63.9 \%$ for men and $78.7 \%$ for the total population. ${ }^{[11]}$ In our study, the rate of "alcohol nonconsumers" was $79.6 \%$ and $49.2 \%$ for women and men, respectively. The rate for having first-degree relatives who have a habit of consuming alocohol was higher among females in our study. This is not surprising because most of the relatives mentioned as "alcohol consumers" were males (fathers, brothers, husbands, etc). One of the inclusion criteria for our study was that the subjects had to be over 18 -years-old or older. 
The age limits in our investigation together with the information reported by the Ministry of Health may offer reasons for the discrepancy regarding the higher rate among females. We did not have opportunity to compare these figures via age-adjusted correction, but we can hypothesize that these figures should be near each other. Therefore, we can assume that the results for our study population are similar to the general population, but more research would be needed to confirm this. Most people in our country are Muslims, and alcohol intake is forbidden by Islamic rules; therefore drinking alcohol is not considered to be a custom for social interactions in the Turkish population. The high rate of "alcohol non-consumers" reported is not surprising. The honesty of the subjects while answering the requested questions may be an important factor in determining the results, but it is impossible to reveal such an effect objectively.

In our study, the alcohol consumption rates for AS and RA patients, without considering gender difference, were $36.9 \%$ and $23.0 \%$, respectively. The alcohol consumption rate of the latter group was statistically lower than that of the healthy controls, and the rates between the AS and control groups had no statistical significance. An earlier study had revealed a lower rate of alcohol consumption among women with arthritis. ${ }^{[2]}$ The lower rate of alcohol consumed in the RA group may be explained by the relative female dominance of the subjects within this group, but no statistical difference in alcohol consumption between genders was seen in this group. On the other hand, there was a significant difference between genders with the AS patients. The alcohol consumption habits of the RA and AS groups were statistically different $(\mathrm{p}=0.042)$. In previous reports, there were possible explanations for the similar conditions. The low incidence of alcohol-related deaths among RA patients was interpreted as a reflection that alcohol consumption leads to protection against disease. ${ }^{[3]}$ The association of alcohol consumption and the reduced risk and severity of RA was mentioned in several other reports. ${ }^{[12-14]}$ The mechanism of this protective effect is still unclear; however, it is not logical to draw such a conclusion through the finding of "low incidence of alcohol consumption among RA patients". Our investigation did not seek to explore the attributed risk of alcohol consumption to having RA or try to determine its severity when present. The other suggested explanation for the low incidence of alcoholassociated events in RA patients was the reduction of patients after being diagnosed of RA. One of the suggested reasons for this was increased joint pain associated with alcohol consumption. ${ }^{[3]}$ However, in our study, we had no patient that reported an increase in pain after consuming alcohol.

The rate of alcohol consumption in the AS group in our study was higher than the RA group, but it did not differ statistically from the control group. Our results demonstrated that the "alcohol-consumers" in the AS and control groups were predominantly males, so the higher rates of alcohol consumption relative to the RA group may be partly explained by this predominance. Myllykangas-Luosujärvi et al. ${ }^{[4]}$ suggested two possible explanations for the association of alcohol-related events in AS patients. The first possibility was the aggrevation of pain in AS patients due to lifestyle alterations in addition to alcohol consumption or other addiction such as smoking. The second possible reason was the probability that the emotional problems created by the pain of AS may cause so-called "relief drinking". Sirmalı et al. ${ }^{[15]}$ defined AS as a perturbing psychosocial concern and suggested the necessity of using the psychotherapeutic approach to deter AS patients from consuming alcohol and smoking. In our study, only two patients with AS confessed that they had used alcohol for analgesia. Nevertheless, since there is no report in favor of the protective role of alcohol regarding AS, preventive measures against alcohol consumption should be considered.

We used the MAST as a screening test to determine whether our subjects had a problem with alcohol consumption. Actually, this method is an old and difficult one to apply. Nevertheless, most of our subjects successfully completed the test. According to our results, the mean MAST score was statistically higher in the control group than in the other two groups. By categorizing the MAST score we found that only four subjects were within the highest category (MAST score of 10 or more). These four subjects were males and belonged to the control group. In general, higher MAST scores represent an increased risk for problematic alcohol drinking. ${ }^{[9]}$ Our analysis revealed that our subjects generally had a low risk for alcohol-related events. Hence, our results are in contrast to those of Myllykangas-Luosujärvi et al. ${ }^{[4]}$ As mentioned previously, the results our study depended on the honesty of our subjects when filling out the questionnaire, and this subjectivity can not be accounted for by any objective method.

This study was only a cross-sectional investigation and was designed in order to define the alcohol consumption habits of patients with inflammatory 
rheumatic disease. Our research was not concerned with the other possible factors which may have had a determining role on the alcohol consumption habits of the individuals. Incidentally, we found an inverse relationship between the probability of "problematic alcohol consumption" and the educational status of our subjects. The psychological profile of the participants, their total financial income, and their ability to obtain alcohol are just some of the potential determining factors for alcohol consumption, and further research is needed to make any conclusions regarding their exact effect. There were no questions concerning these factors in our study, which was a major flaw. On the other hand, our study was comprised of more than 300 people; hence, the sheer numbers of participants justifies the purpose of our study. The final results of this investigation, some of which are interesting and different from the general population, make our study valuable. The higher number of AS patients who have a habit of alcohol consumption should especially be kept in mind. All of the "problematic drinkers" belonged to the control group, and their numbers were very low.

In conclusion, we found that alcohol consumption was low in our rheumatic patients. These findings should be interpreted with caution because many of the drugs used for the treatment of rheumatic diseases are potentially hepatotoxic. Our results need to be verified by further studies, and these should be designed in a manner so as to explore the other possible factors which may determine alcohol consumption properties and their consequences on the health status of patients.

\section{Declaration of conflicting interests}

The authors declared no conflicts of interest with respect to the authorship and/or publication of this article.

\section{Funding}

The authors received no financial support for the research and/or authorship of this article.

\section{REFERENCES}

1. Riley JL 3rd, King C. Self-report of alcohol use for pain in a multi-ethnic community sample. J Pain 2009;10:944-52.
2. Bradlow A, Mowat AG. Alcohol consumption in arthritic patients: clinical and laboratory studies. Ann Rheum Dis 1985;44:163-8.

3. Myllykangas-Luosujärvi R, Aho K, Kautiainen H, Hakala M. Reduced incidence of alcohol related deaths in subjects with rheumatoid arthritis. Ann Rheum Dis 2000;59:75-6.

4. Myllykangas-Luosujärvi R, Aho K, Lehtinen K, Kautiainen $\mathrm{H}$, Hakala $\mathrm{M}$. Increased incidence of alcohol-related deaths from accidents and violence in subjects with ankylosing spondylitis. Br J Rheumatol 1998;37:688-90.

5. Chen CC, Yin SJ. Alcohol abuse and related factors in Asia. Int Rev Psychiatry 2008;20:425-33.

6. Bilgin-Cengiz D. GfK arastırdı, Türklerin yüzde 83 'ü hiç alkol kullanmaz çıktı. Available from: http:/hurarsiv. hurriyet.com.tr/goster/haber.aspx?id=10518988\&tar $\mathrm{ih}=2008-12-6$.

7. Harris ED. Clinical features of rheumatoid arthritis. In: Harris ED, Budd RC, Genovese MC, editors. Kelley's textbook of rheumatology. 7th ed. Philadelphia: Elsevier Saunders; 2005. p. 1043-78.

8. Olivieri I, van Tubergen A, Salvarani C, van der Linden S. Seronegative spondyloarthritides. Best Pract Res Clin Rheumatol 2002;16:723-39.

9. Coşkunol H, Bağdiken İ, Sorias S, Saygılı R. Validity of michigan alcoholism screening test. Ege Tip Dergisi 1995;34:15-8.

10. Turan M, Aşkın R. Psychiatric symptoms at alcohol dependency. Genel Tip Derg 1999;9:93-8.

11. Mollahaliloğlu S, Bora Başaran B, Eryılmaz Z. The ministry of health of Turkey health statistics yearbook 2010. School of Public Health, Refik Saydam Hygiene Center Presidency, Ministry of Health of Turkey, Ankara: 2011. p. 37.

12. Källberg H, Jacobsen S, Bengtsson C, Pedersen M, Padyukov L, Garred P, et al. Alcohol consumption is associated with decreased risk of rheumatoid arthritis: results from two Scandinavian case-control studies. Ann Rheum Dis 2009;68:222-7.

13. Nissen MJ, Gabay C, Scherer A, Finckh A; Swiss Clinical Quality Management Project in Rheumatoid Arthritis. The effect of alcohol on radiographic progression in rheumatoid arthritis. Arthritis Rheum 2010;62:1265-72.

14. Maxwell JR, Gowers IR, Moore DJ, Wilson AG. Alcohol consumption is inversely associated with risk and severity of rheumatoid arthritis. Rheumatology (Oxford) 2010;49:2140-6.

15. Sirmali M, Ozçakar L, Findik G, Kaya S. Ankylosing spondylitis: a perturbing psychosocial concern? Rheumatol Int 2003;23:324-5. 